\title{
Kinerja Gabungan Kelompok Tani Kasus: Kabupaten Lampung Selatan Provinsi Lampung
}

\section{Association of Farmer Group Performance Study at South Lampung Regency Lampung Province}

\author{
Fauziah Y. Adriyani ${ }^{1}$, Aida Vitayala S. Hubeis ${ }^{2}$, dan Richard W.E. Lumintang ${ }^{2}$ \\ ${ }^{1}$ Penyuluh BPTP Lampung \\ ${ }^{2}$ Departemen Sains Komunikasi dan Pengembangan Masyarakat \\ Fakultas Ekologi Manusia IPB
}

\begin{abstract}
The objectives of this research were to identify the internal and external factors related to Gapoktan performance and also to analyst the relation among the internal and external factors. The research conducted in March-May 2010 in South Lampung regency Lampung Province, the data were collected by interview technique using questionners to key persons. A number of 184 farmer groups respondents participated were randomized sampling from 20 sample of Gapoktan. Descriptive statistic and rank Spearman Correlation Test from SPSS 17.00 were used to analize the data. The result showed that internal factors such as farmer group activity, farmer group cohessivity, interaction among farmer group, the structure of Gapoktan's organization, and leadership had positive and significant correlation with Gapoktan performance. While the position of farmer group, farmer group participation, and desicion making process had non significant correlation with Gapoktan performance. The external factors such as goverment policy, relationship with the other institution, capital loan, and extension intensity had positive and significant correlation with Gapoktan performance. Meanwhile, the change agent (PPL) performance had non significant correlation with Gapoktan performance. Most of variable both internal and external factors had a positive and significant relation to each others.
\end{abstract}

Keywords: performance, associatian of farmer group, Gapoktan

\begin{abstract}
Abstrak
Tujuan dari penelitian ini adalah untuk mengidentifikasi faktor-faktor internal dan eksternal yang berhubungan dengan kinerja Gapoktan dan juga analisis hubungan antara faktor-faktor internal dan eksternal. Penelitian dilakukan pada bulan Maret-Mei 2010 di Kabupaten Lampung Selatan, Provinsi Lampung. Data dikumpulkan dengan teknik wawancara menggunakan angket terhadap orang-orang kunci (yang terpilih). Sejumlah 184 responden kelompok tani berpartisipasi yang ditetapkan secara acak dari 20 sampel Gapoktan. Statistik deskriptif dan uji korelasi rank Spearman dari SPSS 17.00 digunakan untuk menganalisis data. Hasil penelitian menunjukkan bahwa faktor internal seperti aktivitas kelompok tani, kohesivitas kelompok tani, interaksi antar kelompok tani, struktur organisasi Gapoktan, dan kepemimpinan memiliki hubungan positif dan signifikan dengan kinerja Gapoktan. Sedangkan posisi kelompok tani, partisipasi kelompok tani, dan proses pembuatan keputusan memiliki korelasi yang tidak signifikan dengan kinerja Gapoktan. Faktor eksternal seperti kebijakan pemerintah, hubungan dengan lembaga lain, pinjaman modal, dan intensitas penyuluhan, memiliki hubungan positif dan signifikan dengan kinerja Gapoktan. Sementara itu, kinerja PPL memiliki korelasi non signifikan dengan kinerja Gapoktan. Sebagian besar variabel, baik internal maupun eksternal memiliki hubungan positif dan signifikan terhadap yang lain.
\end{abstract}

Kata kunci : kinerja, asosiasi kelompok tani, Gapoktan

\section{Pendahuluan}

Pembentukan Kelompok Tani (Poktan) dan Gabungan Kelompok Tani (Gapoktan) sebagai kelembagaan pertanian pada dasarnya bertujuan untuk meningkatkan efektivitas dan efisiensi petani dalam berusahatani. Selain itu dengan adanya Poktan dan Gapoktan maka petani dapat lebih mudah memperoleh infor- masi yang akurat mengenai segala hal yang bermanfaat bagi kemajuan usahanya, mulai dari persiapan tanam sampai dengan budidaya, cocok tanam dan bahkan pemasaran produk. Penyuluhan pertanian berkaitan dengan usaha penyampaian informasi dan dengan seringnya suatu informasi baru dibicarakan menyebabkan informasi mudah diingat. Berdasarkan hal 
tersebut, dapat dikatakan bahwa keberadaan Poktan dapat mempercepat proses difusi inovasi.

Pemanfaatan Poktan dalam berbagai program Kementan sudah sejak lama digunakan, tetapi pemanfaatan Gapoktan yang merupakan gabungan dari beberapa Poktan baru dimasyarakatkan mulai tahun 2005 di beberapa provinsi termasuk Provinsi Lampung pada Program Rintisan dan Akselerasi Pemasyarakatan Inovasi Teknologi Pertanian (Prima Tani). Sebelumnya, penggabungan beberapa Poktan juga telah dilakukan pada program Peningkatan Produktivitas Padi Terpadu (P3T) sejak tahun 2002 dalam bentuk Kelompok Usaha Agribisnis Terpadu (KUAT) sebanyak 14 KUAT di 14 provinsi.

Pembentukan Gapoktan sendiri didasarkan pada visi pembangunan pertanian yaitu pertanian modern tidak hanya identik dengan mesin pertanian yang modern tapi perlu adanya organisasi yang dicirikan dengan organisasi ekonomi yang mampu menyentuh dan menggerakkan perekonomian di perdesaan (Deptan 2006a). Berdasarkan visi tersebut, pada tahun 2008 melalui program Pengembangan Usaha Agribisnis Perdesaan (PUAP) dibentuk 10.000 Gapoktan sebagai organisasi yang mengelola dana bantuan langsung masyarakat yang diberikan pada setiap desa pelaksana program PUAP.

Penggabungan beberapa Poktan dalam satu wadah organisasi bertujuan untuk meningkatkan efektivitas dan efisiensi berusahatani serta meningkatkan posisi tawar petani dalam memasarkan hasilnya. Pembentukan Gapoktan dapat berdampak positif seperti meningkatnya posisi tawar petani sehingga meningkatkan pendapat dan kesejahteraan. Pembentukan Gapoktan bukan tidak mungkin berdampak negatif seperti munculnya konflik antar Poktan yang pada akhirnya dapat memecah anggota masyarakat apabila Gapoktan tersebut tidak dapat menjalankan fungsinya dengan baik. Salah satu penyebab tidak berjalannya fungsi Gapoktan tersebut dapat dilihat dari faktor internal yang terjadi dalam Poktan dan faktor eksternal yang berhubungan dengan berfungsinya Gapoktan.
Secara spesifik tujuan penelitian penelitian ini ingin menjawab pertanyaan-pertanyaan tentang bagaimana kinerja Gapoktan di Kabupaten Lampung Selatan, faktor internal apa saja yang berhubungan dengan kinerja Gapoktan?, dan faktor eksternal apa saja yang berhubungan dengan kinerja Gapoktan?

\section{Metode Penelitian}

Penelitian ini didesain sebagai penelitian survey bersifat dekriptif korelasional dan menggunakan pendekatan kuantitatif yang bertujuan untuk menjelaskan kinerja Gapoktan, hubungan faktor internal dengan kinerja Gapoktan, dan hubungan faktor eksternal dengan kinerja Gapoktan.

Penelitian dilaksanakan pada bulan Maret s/d Mei 2010 di Kabupaten Lampung Selatan Provinsi Lampung. Lokasi penelitian dipilih secara sengaja atau purposive.

Gapoktan di Kabupaten Lampung Selatan berjumlah 197 Gapoktan sedangkan populasi Gapoktan pada penelitian ini adalah Gapoktan dengan kriteria: berbadan hukum, terbentuk tahun 2007 atau sebelumnya supaya dapat terlihat kinerjanya, dan wilayah lahan kering. Berdasarkan hal tersebut didapatkan populasi penelitian berjumlah 32 Gapoktan. Sampel diambil secara acak sederhana dari populasi menggunakan tabel nomor acak dengan jumlah sampel ditentukan sebanyak 20 Gapoktan yang terdiri dari lima Gapoktan homogen (memiliki satu jenis usaha komoditas) dan 15 Gapoktan heterogen (memiliki lebih dari dua jenis usaha komoditas). Responden penelitian berjumlah 184 kelompok tani.

Jenis data dalam penelitian ini adalah data primer dan sekunder. Data primer yang dikumpulkan adalah peubah utama yang diteliti berupa faktor internal, faktor eksternal dan kinerja Gapoktan. Data sekunder yang dikumpulkan berkaitan dengan keadaan umum atau potensi aktual mengenai kondisi geografis dan data kondisi umum Poktan dan Gapoktan. Data diperoleh dengan cara: wawancara dengan responden menggunakan kuesioner yang sudah dipersiapkan, pencatatan kejadian selama penelitian, pengamatan terhadap kondisi wilayah, dan penelusuran dokumen terkait. 


\section{Kinerja Gapoktan}

Rataan skor kinerja pada Gapoktan homogen secara umum lebih rendah daripada Gapoktan heterogen. Berdasarkan pengamatan diketahui bahwa sebagian besar responden Poktan pada Gapoktan homogen menilai bahwa tidak terdapat perencanaan dalam menyusun kegiatan yang dilakukan Gapoktan, sehingga sebagian besar kegiatan Gapoktan mengalami kemacetan dan berpengaruh pada pertambahan modal. Responden Poktan pada Gapoktan heterogen sebagian menilai bahwa terdapat perencanaan yang baik dalam menentukan kegiatan Gapoktan tetapi tidak seluruh kegiatan mampu berjalan dengan baik.

\section{Pencapaian Tujuan Gapoktan}

Kegiatan yang dilaksanakan oleh Gapoktan homogen tidak mampu berjalan baik karena tidak direncanakan sehingga pencapaian tujuan berkategori rendah. Kegiatan yang dilaksanakan oleh Gapoktan heterogen hanya sebagian saja yang mampu berjalan baik dan sesuai dengan tujuan yang ingin dicapai sehingga masuk dalam kategori sedang.

Sebagian besar responden Poktan menyatakan bahwa tujuan Gapoktan terdapat dalam AD/ART. Tujuan Poktan merupakan suatu gambaran tentang suatu kondisi yang ingin dicapai oleh Poktan, sehingga diperlukan beragam usaha dari anggota untuk mencapainya. Dengan demikian, tujuan Poktan menentukan usaha yang dilakukan oleh Poktan sehingga tujuan Poktan merupakan hal yang harus ada dalam Poktan.

Sebagian kecil responden Poktan menyatakan bahwa seluruh anggota Gapoktan mengetahui tujuan Gapoktan. Tujuan harus diketahui dengan jelas oleh anggotanya. Usaha dalam pencapaian tujuan dilaksanakan oleh setiap individu/anggotanya. Konsekuensinya, tujuan Gapoktan harus jelas diketahui oleh anggotanya karena tujuan yang jelas setiap anggota mampu berperan aktif dalam menentukan usaha yang dilakukan dalam mencapai tujuan.

Sebagian besar responden Poktan menyatakan bahwa kegiatan yang dilakukan Gapoktan telah sesuai dengan tujuan yang ingin dicapai. Sebagian responden Poktan menyatakan bahwa pelaksanaan kegiatan Gapoktan berhasil dengan baik.

Sebagian besar responden Poktan menyatakan bahwa keberadaan Gapoktan berdampak pada peningkatan produksi akibat adanya kemudahan berusahatani. Sebagian kecil responden Poktan menyatakan bahwa keberadaan Gapoktan berdampak pada peningkatan pendapatan. Adanya kebijakan pemerintah mengenai penyaluran pupuk bersubsidi melalui kios berdasarkan jumlah kebutuhan pupuk dalam rencana definitif kebutuhan Poktan (RDKK) menyebabkan pembentukan Gapoktan mempermudah petani untuk mendapatkan saprodi.

Perkembangan Usaha. Perkembangan usaha pada Gapoktan homogen lebih rendah daripada Gapoktan heterogen. Kondisi usaha di sebagian besar Gapoktan homogen tidak mengalami perkembangan bahkan terdapat Gapoktan yang tidak lagi memiliki kegiatan (pasif). Kondisi di sebagian Gapoktan heterogen menunjukkan kegiatan Gapoktan mampu berjalan dengan baik tetapi kegiatan tersebut tidak memberikan kontribusi bagi penambahan modal.

Sebagian kecil responden Poktan menyatakan bahwa jumlah kegiatan Gapoktan bertambah dari mulai pembentukan sampai sekarang. Sebagian responden Gapoktan menyatakan bahwa usaha yang dilakukan Gapoktan berjalan dengan baik, sedangkan yang lain menyatakan bahwa usaha Gapoktan tidak berjalan dengan baik (mengalami kemacetan). Sebagian besar responden Poktan menyatakan bahwa anggota yang merasakan manfaat keberadaan Gapoktan semakin bertambah.

Perkembangan Modal. Perkembangan modal Gapoktan homogen lebih rendah daripada Gapoktan heterogen. Sebagian besar Gapoktan homogen tidak mempunyai simpanan wajib sebagai sumber modal sedangkan sebagian responden Poktan menyatakan bahwa anggota memiliki simpanan wajib di Gapoktan.

Sebagian kecil responden Poktan yang mendapatkan BLM menyatakan bahwa seluruh anggota mampu mengembalikan pinjaman bantuan pemerintah ke Gapoktan, sedangkan 
sebagian besar menyatakan bahwa tidak semua anggota mau dan mampu mengembalikan pinjaman bantuan pemerintah ke Gapoktan. Sebagian kecil responden Poktan menyatakan bahwa usaha bersama yang dilakukan Gapoktan mampu memberikan keuntungan.

Perkembangan modal Gapoktan heterogen lebih tinggi daripada perkembangan modal Gapoktan homogen. Sebagian besar Gapoktan heterogen mendapat dana stimulan berupa dana PUAP senilai Rp.100 juta untuk usaha Gapoktan dan umumnya dibelikan saprodi yang kemudian dipinjamkan ke anggotanya. Berdasarkan hal tersebut Gapoktan heterogen lebih berkembang modalnya. Kondisi dalam Poktan pada kenyataannya tidak terjadi dalam Gapoktan. Sebagian besar Gapoktan di Kabupaten Lampung Selatan tidak memiliki simpanan anggota. Berdasarkan pengamatan, salah satu penyebab kurangnya Gapoktan yang memiliki simpanan anggota adalah adanya trauma anggota untuk menyimpan dana di Gapoktan sehingga hilangnya kepercayaan karena mereka beranggapan Gapoktan sama dengan koperasi yang menghilangkan simpanan mereka. Hal ini sesuai dengan hasil penelitian La porta et al. (Dasgupta dan Ismail, 1999) yang menyatakan bahwa meningkatnya rasa percaya meningkatkan partisipasi dalam setiap kegiatan, dan dalam hal ini adalah kegiatan simpan pinjam.

Tabel 1. Rataan skor kinerja Gapoktan Kabupaten Lampung Selatan

\begin{tabular}{lcc}
\hline \multicolumn{1}{c}{ Kinerja } & \multicolumn{2}{c}{$\begin{array}{c}\text { Jenis usaha komoditas } \\
\text { Gapoktan }\end{array}$} \\
\cline { 2 - 3 } & Homogen & heterogen \\
\hline Pencapaian tujuan & 1,44 & 2,19 \\
Perkembangan usaha & 1,60 & 2,17 \\
Perkembangan modal & 1,20 & 2,10 \\
\hline Keterangan: Kisaran skor 1,00-1,66 (rendah), skor 1,67-2,33 \\
(sedang), skor 2,34-3,00 (tinggi)
\end{tabular}

\section{Hubungan antara Faktor Internal dengan Kinerja Gapoktan}

Nilai keeratan hubungan antara kegiatan Poktan dengan kinerja Gapoktan menunjukkan bahwa kegiatan Poktan lebih berhubungan erat dengan pencapaian tujuan dan perkembangan modal dibandingkan dengan perkembangan usaha. Hal ini dapat dipahami karena
Poktan dengan aktivitas tinggi menunjukkan bahwa Poktan tersebut berjalan dengan baik sehingga apabila Poktan tersebut bergabung dalam Gapoktan maka budaya kerja dalam Poktan tersebut dapat diterapkan juga dalam Gapoktan. Poktan yang terbiasa memiliki kegiatan Poktan yang banyak terbiasa untuk melaksanakan kegiatan dalam mencapai tujuan selain itu, Poktan tersebut memiliki dana/ kas Poktan yang dapat digunakan untuk memupuk modal di Gapoktan. Poktan dengan kegiatan yang tinggi walaupun biasa melakukan kegiatan demi pencapaian tujuan dan memupuk modal dalam Gapoktan, tetapi cenderung kesulitan dalam mengembangkan usaha Gapoktan karena overlap dengan kegiatan Poktan.

Letak Poktan tidak berhubungan nyata dengan kinerja baik pada pencapaian tujuan, perkembangan usaha, dan perkembangan modal Gapoktan dengan demikian hipotesis ditolak. Hal ini berarti mudah atau sulit akses Poktan ke lokasi Gapoktan tidak secara nyata berhubungan dengan peningkatan kinerja Gapoktan. Pada kenyataannya kegiatan maupun kantor Gapoktan berpusat di tengah sehingga akses semua Poktan menuju Gapoktan sama. Selain itu, sebagian besar desa di Kabupaten Lampung Selatan memiliki akses dalam desa yang cukup baik dalam arti tidak ada wilayah/ bagian dari desa yang terisolasi (dipisahkan oleh sungai besar atau lembah) yang menyulitkan hubungan wilayah tersebut dengan wilayah lain. Selain itu, sebagian besar anggota memiliki kendaraan motor yang mempermudah anggota menuju lokasi kegiatan Poktan sehingga menyebabkan mereka tidak mempunyai kendala untuk berpartisipasi dalam kegiatan Gapoktan yang dilakukan untuk mencapai tujuan yang telah ditetapkan.

Kekompakan Poktan pembentuk Gapoktan berhubungan positif sangat nyata dengan kinerja Gapoktan baik pada pencapaian tujuan, perkembangan usaha maupun perkembangan modal, dengan demikian hipotesis diterima. Hal ini berarti semakin tinggi kekompakan anggota dalam Poktan pembentuk Gapoktan maka tercapainya tujuan Gapoktan yang telah ditetapkan semakin tinggi, usaha dan modal Gapoktan semakin berkembang. 
Nilai keeratan hubungan antara kekompakan Poktan dengan kinerja Gapoktan menunjukkan bahwa kegiatan Poktan lebih berhubungan erat dengan pencapaian tujuan dan perkembangan modal dibandingkan dengan perkembangan usaha. Hal ini dapat dipahami karena Poktan yang kompak menunjukkan bahwa anggota Poktan tersebut memiliki rasa kebersamaan (sense of belonging) dengan anggota lain yang tinggi. Menurut Slamet dan Sumardjo (Setiawan 2003), kekompakan kelompok adalah kesatuan dan persatuan kelompok yang membentuk suatu kekuatan. Kekompakan anggota Poktan menyebabkan ketegangan individu dalam menghadapi permasalahan/konflik yang terjadi dalam Poktan dapat berkurang karena konflik yang terjadi dapat diatasi dengan baik. Poktan yang kompak memiliki kinerja yang tinggi karena individu memiliki rasa percaya diri bahwa untuk mengatasi hambatan yang muncul dalam mencapai tujuan dapat dilakukan melalui kebersamaan sehingga tercipta kerjasama dan Poktan dapat menetapkan prosedur kerja. Poktan yang memiliki kekompakan tinggi antar anggotanya cenderung melakukan hal yang sama pada saat digabungkan dengan Poktan lain dalam Gapoktan.

Partisipasi anggota Gapoktan tidak berhubungan nyata dengan kinerja Gapoktan baik pada pencapaian tujuan, perkembangan usaha dan perkembangan modal Gapoktan yang berarti hipotesis ditolak. Hal ini menunjukkan bahwa semakin tinggi partisipasi Poktan tidak diikuti secara nyata dengan peningkatan kinerja Gapoktan. Apabila dikaitkan dengan kekompakan, pada kenyataannya banyaknya
Poktan pembentuk Gapoktan yang kompak tidak sertamerta menyebabkan partisipasi anggota Gapoktan berhubungan dengan kinerja Gapoktan. Hal ini dapat dimaklumi, Sujak (1990) menyatakan bahwa sesuatu yang dianggap efektif dalam Poktan belum tentu efektif oleh organisasi apabila norma yang ditetapkan Poktan berlainan dengan norma organisasi. Setiap kegiatan Gapoktan diusahakan adanya partisipasi semua anggota agar tumbuh perasaan sebagai bagian dari Gapoktan. Gapoktan harus benar-benar terasa sebagai milik anggota bukan milik pengurus. Syarat partisipasi adalah adanya kemauan, kemampuan dan kesempatan, supaya anggota mau menjadi bagian dan diikutsertakan dari mulai perencanaan.

Anggota Poktan pada kenyataannya kurang berpartisipasi dalam kegiatan Gapoktan karena anggota Poktan tidak merasa sebagai anggota. Pemanfaatan Gapoktan dalam pelaksanaan program pembangunan pertanian memiliki konsekuensi perlunya sosialisasi mengingat Gapoktan merupakan hal baru di mana terjadi perubahan struktur dan fungsi suatu sistem sosial. Menurut Rogers dan Shoemaker (1995) proses perubahan sosial terdiri dari tiga tahap berurutan: 1) invensi yaitu proses di mana ide-ide baru diciptakan dan dikembangkan, 2) difusi, ialah proses di mana ide-ide baru itu dikomunikasikan ke dalam sistem sosial, dan 3) konsekuensi yakni perubahan-perubahan yang terjadi dalam sistem sosial sebagai akibat atau pengadopsian atau penolakan inovasi. Perubahan dari Poktan menjadi

Hubungan antara partisipasi anggota

Tabel 2. Hubungan faktor internal dengan Kinerja Gapoktan

\begin{tabular}{lccc}
\hline \multirow{2}{*}{ Faktor internal } & \multicolumn{3}{c}{ Kinerja Gapoktan $\left(\mathrm{r}_{\mathrm{s}}\right)$} \\
\cline { 2 - 4 } & Pencapaian tujuan & Perkembangan usaha & Perkembangan modal \\
\hline Kegiatan Poktan & $0,649^{* *}$ & $0,502^{*}$ & $0,611^{* *}$ \\
Letak Poktan & 0,152 & 0,082 & 0,151 \\
Kekompakan Poktan & $0,818^{* *}$ & $0,729^{* *}$ & $0,821^{* *}$ \\
Partisipasi anggota Gapoktan & 0,412 & 0,313 & 0,421 \\
Interaksi antar Poktan & $0,639^{* *}$ & $0,647^{* *}$ & $0,612^{* *}$ \\
Struktur organisasi Gapoktan & $0,803^{* *}$ & $0,647^{* *}$ & $0,561^{*}$ \\
Proses Pengambilan keputusan & 0,286 & 0,349 & 0,189 \\
Kepemimpinan Pengurus Gapoktan & $0,602^{* *}$ & $0,611^{* *}$ & 0,318 \\
\hline
\end{tabular}

Keterangan: * korelasi nyata $(\mathrm{p}<0,05)$

** korelasi sangat nyata $(\mathrm{p}<0,01)$

$\mathrm{r}_{\mathrm{S}}=$ Koefisien korelasi rank Spearman 
Gapoktan yang tidak nyata disebabkan ketidakjelasan siapa anggota Gapoktan, apakah hanya pengurus Poktan ataukah seluruh anggota Poktan. Sosialisasi perlu dilakukan untuk memberikan pengertian kepada seluruh anggota Poktan bahwa tanpa adanya partisipasi dari seluruh anggota Poktan di setiap kegiatan yang dilakukan maka Gapoktan tidak dapat menjalankan fungsinya secara optimal. Popenoe (1989) menyatakan bahwa melalui sosialisasi, anggota mengenal organisasi, nilai dan norma organisasi dan belajar bagaimana mengerjakan tugasnya.

Interaksi antar Poktan berhubungan positif sangat nyata dengan kinerja Gapoktan pada pencapaian tujuan dan perkembangan usaha serta berhubungan positif nyata dengan perkembangan modal Gapoktan yang berarti hipotesis diterima. Hal ini menunjukkan bahwa semakin tinggi interaksi yang dilakukan antar Poktan pembentuk Gapoktan diikuti dengan peningkatan kinerja Gapoktan.

Hasil uji statistik menunjukkan bahwa interaksi antar Poktan berhubungan positif dan nyata dengan kinerja Gapoktan. Sanders (1958) menyatakan bahwa masing-masing kelompok cocok atau sesuai dalam berproses dalam masyarakat dan jika mereka telah berhasil berjalan selaras dengan kelompok lain (kelompok lain yang memiliki karakteristik yang sama dijadikan referensi dalam berproses). Seperti halnya kelompok dalam masyarakat, Poktan yang tergabung dalam Gapoktan harus berjalan selaras dengan Poktan lainnya. Gapoktan merupakan salah satu contoh organisasi dimana setiap anggotanya harus bekerjasama dan berkoordinasi dengan anggota-anggota lainnya agar dapat mencapai tujuan bersama. Dengan kata lain tingkat ketergantungan antar anggota Poktan sangat tinggi dan semua anggota saling berkomunikasi. Tanpa adanya kerjasama dan koordinasi dalam melakukan kegiatan, maka Gapoktan tidak dapat menjalankan fungsinya dengan baik dengan kata lain kinerja Gapoktan dipengaruhi oleh interaksi yang terjadi pada anggotanya, semakin baik interaksi yang terjadi maka kinerja Gapoktan menjadi semakin baik.
Struktur organisasi Gapoktan berhubungan positif sangat nyata dengan kinerja Gapoktan yaitu pencapaian tujuan dan perkembangan usaha serta berhubungan positif nyata dengan perkembangan modal Gapoktan yang berarti hipotesis diterima. Hal ini menunjukkan bahwa semakin baik struktur organisasi Gapoktan diikuti dengan peningkatan kinerja Gapoktan. Hasil ini sesuai dengan penelitian Wahyuni (2003) yang menyimpulkan bahwa faktor yang mempengaruhi kinerja kelompok antara lain adalah struktur kelompok.

Nilai keeratan hubungan antara struktur organisasi Gapoktan dengan kinerja Gapoktan menunjukkan bahwa struktur organisasi lebih berhubungan erat dengan pencapaian tujuan dan perkembangan usaha dibandingkan dengan perkembangan modal. Hal ini dapat dipahami karena stuktur Gapoktan pada dasarnya menggambarkan peran dan hubungan antar anggota. Menurut Popenoe (1989) peran merupakan perilaku yang diharapkan dari seseorang dengan memberikan status dalam kelompok atau masyarakat. Ketidakjelasan dan ketidaktahuan anggota Gapoktan terhadap struktur Gapoktan menyebabkan anggota tidak mampu menjalankan perannya dalam Gapoktan.

Gapoktan yang memiliki kinerja kurang baik memiliki struktur Gapoktan yang tidak diketahui secara jelas oleh anggotanya, ketidakjelasan struktur berpengaruh terhadap ketidakjelasan kedudukan, peran, hak dan kewajiban, serta kekuasaan anggotanya, sehingga pelaksanaan kegiatan tidak mungkin dapat berlangsung secara efektif dan efisien untuk mencapai tujuan Gapoktan dan perkembangan usaha. Kenyataan di lokasi penelitian menunjukkan bahwa sebagian besar Gapoktan memiliki struktur organisasi seragam yang dibuat berdasarkan pedoman umum dari Kementerian Pertanian tanpa disesuaikan dengan kebutuhan dan sumberdaya alam dan manusia yang dimiliki oleh Gapoktan.

Proses pengambilan keputusan dalam Gapoktan tidak berhubungan nyata dengan kinerja Gapoktan baik pada pencapaian tujuan, perkembangan usaha dan perkembangan modal Gapoktan. Hal ini menunjukkan bahwa 
Tabel 3. Hubungan faktor eksternal dengan Kinerja Gapoktan

\begin{tabular}{lccc}
\hline \multirow{2}{*}{ Faktor eksternal } & \multicolumn{3}{c}{ Kinerja Gapoktan $\left(\mathrm{r}_{\mathrm{s}}\right)$} \\
\cline { 2 - 4 } & $\begin{array}{c}\text { Pencapaian } \\
\text { tujuan }\end{array}$ & $\begin{array}{c}\text { Perkembangan } \\
\text { usaha }\end{array}$ & $\begin{array}{c}\text { Perkembangan } \\
\text { modal }\end{array}$ \\
\hline Kebijakan pemerintah & $0,822^{* *}$ & $0,633^{* *}$ & $0,482^{*}$ \\
Hubungan dengan lembaga lain & $0,612^{* *}$ & $0,547 *$ & $0,479^{*}$ \\
Bantuan permodalan & $0,484^{*}$ & $0,489 *$ & $0,669^{* *}$ \\
Intensitas penyuluhan & $0,715^{* *}$ & $0,558^{*}$ & $0,602^{* *}$ \\
Kinerja PPL & 0,338 & 0,111 & 0,161 \\
\hline Keterangan: & $*$ korelasi nyata $(\mathrm{p}<0,05)$ & $\mathrm{r}_{\mathrm{s}}=$ Koefisien korelasi rank Spearman & \\
\multicolumn{2}{c}{ korelasi sangat nyata $(\mathrm{p}<0,01)$} & &
\end{tabular}

semakin baik proses pengambilan keputusan dalam Gapoktan tidak secara nyata diikuti dengan peningkatan kinerja Gapoktan.

Hasil uji statistik menunjukkan bahwa proses pengambilan keputusan tidak berhubungan nyata dengan kinerja Gapoktan. Setiap keputusan yang diambil Gapoktan sebagian besar melalui proses musyawarah untuk mufakat dalam suatu forum yang dihadiri perwakilan/pengurus Poktan pembentuk Gapoktan. Tidak setiap keputusan ditetapkan dengan surat keputusan, tapi tetap dicatat dalam notulen rapat yang ditanda tangani pengurus dan perwakilan anggota. Hasil keputusan tidak disosialisasikan kepada anggota Gapoktan yang lain karena pembina baik PPL maupun BP4K Lampung Selatan berpendapat bahwa anggota Gapoktan adalah perwakilan/pengurus Poktan saja tidak termasuk anggotanya. Hal ini menyebabkan anggota Poktan yang juga seharusnya anggota Gapoktan tidak mau berperan aktif dan tidak diberitahu mengenai hasil pengambilan keputusan.

Kepemimpinan pengurus Gapoktan berhubungan positif sangat nyata dengan kinerja Gapoktan pada pencapaian tujuan dan perkembangan usaha yang berarti hipotesis diterima tetapi berhubungan positif tidak nyata dengan perkembangan modal. Hal ini menunjukkan bahwa semakin baik kepemimpinan pengurus diikuti dengan peningkatan kinerja Gapoktan pada pencapaian tujuan dan perkembangan usaha tapi tidak secara nyata meningkatkan modal Gapoktan.

Popenoe (1989) menyatakan bahwa kepemimpinan berada pada semua level organisasi dan tidak ada organisasi yang bisa berfungsi efektif tanpa adanya kepemimpinan.
Tiga dimensi kepemimpinan diidentifikasikan sebagai berikut: (1) pembuat keputusan; (2) administrasi, memastikan kebijakan berjalan dan kegiatan Poktan terkoordinasi dengan baik; dan (3) monitoring, menilai kinerja secara terus menerus untuk menentukan apakah perubahan diperlukan. Terkadang penampilan dan kepribadian pemimpin mempengaruhi aktivitas dan loyalitas anggota organisasi.

\section{Hubungan antara Faktor Eksternal dengan Kinerja Gapoktan}

Kebijakan pemerintah yang mendukung kerja Gapoktan berhubungan positif sangat nyata dengan kinerja Gapoktan pada pencapaian tujuan, perkembangan usaha serta berhubungan positif nyata dengan perkembangan modal Gapoktan yang berarti hipotesis diterima. Hal ini menunjukkan bahwa semakin banyak kebijakan pemerintah yang mendukung kerja Gapoktan diikuti dengan peningkatan kinerja Gapoktan.

Gapoktan merupakan salah satu organisasi yang dibentuk oleh pemerintah, berjalannya fungsi Gapoktan perlu didukung oleh kebijakan pemerintah yang menciptakan suasana yang kondusif bagi kegiatan yang dilaksanakan. Gapoktan yang sudah mencoba melakukan kegiatan pemasaran hasil pada kenyataannya terkendala karena pemerintah tidak mampu menjamin harga produk dan pasar produk terutama saat panen raya atau adanya permainan yang dilakukan oleh pemerintah sendiri untuk menekan harga produk yang dihasilkan Gapoktan, seperti tidak diterimanya beras petani di Bulog karena menurut Bulog tidak memenuhi syarat.

Hubungan dengan lembaga lain berhubungan positif sangat nyata dengan kinerja 
Gapoktan pada pencapaian tujuan serta berhubungan positif nyata dengan perkembangan usaha dan modal Gapoktan yang berarti hipotesis diterima. Hal ini menunjukkan bahwa semakin tinggi hubungan atau kerjasama Gapoktan dengan lembaga lain diikuti dengan peningkatan kinerja Gapoktan.

Sanders (1958) menyatakan bahwa tak ada hubungan sosial (kelompok) yang berjalan sendiri, pasti terjadi interaksi dengan kelompok lain dan dengan masyarakat yang majemuk dimana mereka berada. Umumnya, sebuah kelompok dapat menjadi bagian dari masyarakat (diterima oleh masyarakat) jika mereka ikut berperan dalam masyarakat.

Tercapainya tujuan dan berjalannya fungsi suatu kelompok atau organisasi tidak terlepas dari pengaruh lembaga lain. Hubungan suatu kelompok dengan lembaga lain pada dasarnya berguna untuk mendapatkan input bagi kelompok ataupun menyalurkan output yang dihasilkan kepada lembaga lainnya. Gapoktan dalam melakukan kegiatannya, seharusnya mampu menjalin hubungan dan kerjasama dengan pihak lain seperti kerjasama penyediaan saprodi dengan produsen benih, pupuk, dan pestisida; kerjasama pemasaran produk Gapoktan seperti pabrik pakan ternak dan pabrik olahan lainnya; dan kerjasama dengan perbankan atau pihak swasta lainnya dalam hal penyedia modal.

Gapoktan di Kabupaten Lampung Selatan sebagian besar hanya mampu melakukan kerjasama dengan kios dan produsen pestisida sebagai penyedia saprodi yang dibutuhkan anggotanya. Hal ini dapat dijelaskan bahwa tanpa adanya hubungan atau kerjasama dengan lembaga lain, Gapoktan tidak mampu mendapatkan input yang baik seperti pupuk (harga maupun kualitas) dan lebih lanjut untuk mendapatkan modal atau bantuan kredit dari lembaga perbankan. Selain itu, Gapoktan tidak mampu untuk memasarkan hasil dengan baik karena pada kenyataannya peningkatan posisi tawar Gapoktan melalui penjualan dalam jumlah besar harus diikuti dengan kerjasama yang baik dengan lembaga pemasaran. Pada akhirnya kondisi tersebut berdampak pada kinerja Gapoktan baik pencapaian tujuan, perkembangan usaha maupun perkembangan modal.

Bantuan permodalan berhubungan positif dan nyata dengan pencapaian tujuan Gapoktan, perkembangan usaha, dan perkembangan modal Gapoktan. Semakin banyak bantuan permodalan yang diterima Gapoktan maka tujuan Gapoktan semakin mudah tercapai, usaha, dan modal Gapoktan semakin berkembang. Bantuan permodalan baik dalam bentuk kredit oleh lembaga keuangan/perbankan maupun BLM oleh pemerintah sangat diperlukan untuk mendukung kegiatan Gapoktan. Hal ini didukung oleh Hermanto (1996) yang menyatakan bahwa kredit merupakan modal operasional yang mendukung kegiatan produksi. Pernyataan tersebut juga didukung oleh penelitian Tamba (2007) yang menyatakan bahwa tersedianya akses modal mempengaruhi kemampuan petani dalam merencanakan dan melaksanakan usahatani/ternak serta kemampuan dalam mengatasi masalah usahataninya.

Bantuan permodalan secara positif dan nyata berhubungan dengan kinerja Gapoktan. Gapoktan merupakan organisasi sukarela yang mengandalkan simpanan anggota sebagai modal bagi kegiatan yang dilakukan. Permasalahannya, anggota Gapoktan adalah petani yang tidak semua mampu menyisihkan dana dalam jumlah besar sebagai simpanan di Gapoktan sehingga modal yang terkumpul dari simpanan anggota tidak cukup untuk meningkatkan kinerja Gapoktan baik dalam rangka efisiensi biaya usahatani maupun meningkatkan pendapatan anggota melalui meningkatnya posisi tawar Gapoktan dalam pemasaran hasil. Berdasarkan hal tersebut, bantuan permodalan merupakan pemecahan masalah modal dalam Gapoktan. Semakin banyak bantuan modal maka Gapoktan semakin mampu untuk mengadakan transaksi baik dengan produsen saprodi maupun konsumen produk Gapoktan dan secara bertahap mampu Gapoktan mampu mengembangkan usahanya.

Hal yang perlu diperhatikan dalam faktor bantuan permodalan adalah bagaimana mengelola bantuan tersebut agar jumlahnya bertambah dan berkembang. BLM PUAP diberikan dalam bentuk uang tunai dan bukan 
merupakan pinjaman (tidak sama dengan kredit usaha tani/KUT) yang tidak ada keharusan bagi anggota Gapoktan penerima PUAP untuk mengembalikannya. Pembina harus memberikan sosialisasi bahwa walaupun dana PUAP tersebut tidak dikembalikan ke pemerintah tetapi penerima bantuan harus mengembalikan dana tersebut beserta uang jasa (sebelumnya telah ditetapkan besarnya) kepada Gapoktan untuk selanjutnya dikembangkan.

Hasil uji statistik rank Spearman menunjukkan intensitas penyuluhan dengan pencapaian tujuan, perkembangan usaha dan modal Gapoktan berhubungan positif dan nyata. Semakin tinggi intensitas penyuluhan di Gapoktan maka tujuan Gapoktan semakin mudah tercapai, usaha, dan modal Gapoktan semakin berkembang.

Hal ini dapat dijelaskan bahwa dengan adanya penyuluhan yang dilakukan oleh PPL dan perusahaan swasta mampu meningkatkan produktivitas dan pada akhirnya meningkatkan pendapatan petani. Dengan meningkatnya pendapatan petani, petani dapat lebih aktif mengikuti kegiatan Gapoktan dan lebih mampu untuk melakukan pemupukan modal Gapoktan melalui simpanan wajib. Hasil ini sesuai dengan hasil penelitian Subarna et al. (2006) yang menyatakan bahwa penyuluhan berpengaruh positif terhadap kinerja kelompok usaha agribisnis terpadu di mana tingginya interaksi antara penyuluh dengan petani menjadikan pertemuan tersebut menjadi tempat diskusi, belajar bagi petani dan penyuluh untuk berusahatani lebih baik.

Hasil uji statistik rank Spearman menunjukkan kinerja PPL tidak berhubungan nyata dengan kinerja Gapoktan. Hasil ini bertentangan dengan pernyataan Hermanto (2007) yang menyatakan bahwa keterbatasan PPL menyebabkan pembinaan Poktan tidak dilakukan secara optimal sehingga eksistensi dan kinerja Poktan masih memprihatinkan dengan kata lain, apabila peranan penyuluh pertanian rendah maka kinerja Poktan juga rendah. Hasil ini juga bertentangan dengan hasil yang didapat oleh Laksono (2005) yang menunjukkan terdapat hubungan nyata antara peranan penyuluh pertanian dan kinerja Poktan dengan nilai koefisien korelasi sebesar
0,735. Yang berarti jika peranan penyuluh pertanian tinggi maka kinerja Poktan juga tinggi.

Kondisi ini dapat dipahami apabila kita mengetahui bahwa terdapat perbedaan dalam Gapoktan dan Poktan sehingga kemampuan yang seharusnya dimiliki oleh PPL untuk membina Gapoktan lebih banyak daripada membina Poktan. Penggabungan beberapa Poktan sebagai kelompok informal ke dalam suatu Gapoktan yang merupakan organisasi formal menyebabkan pembinaan yang dilakukan PPL berbeda. Sebagai kelompok informal, Poktan tidak memiliki kejelasan dokumen pendirian dan tidak ada ketentuan tertulis yang mengikat anggota. Pembinaan yang dilakukan oleh PPL diprioritaskan pada kekompakkan anggota Poktan karena pada kelompok informal pencapaian tujuan disebabkan hubungan antar anggota. Sedangkan sebagai organisasi formal, Gapoktan memiliki dokumen pendirian yang memuat cara organisasi mencapai tujuan sehingga lebih mengikat anggotanya. Hal ini menuntut PPL untuk memiliki kemampuan dalam hal manajemen. Kinerja PPL yang diperlukan dalam usaha meningkatkan kinerja Gapoktan terutama pada peran PPL dalam membangun hubungan antara Gapoktan dengan lembaga lain dan kemampuan PPL dalam memotivasi anggota Gapoktan agar berperan aktif untuk memajukan Gapoktan.

Berdasarkan pengamatan, kedua peran ini tidak dimiliki PPL sehingga pada Gapoktan yang memiliki kinerja baik, faktor eksternal lain lebih berhubungan dengan berjalannya fungsi Gapoktan seperti adanya bantuan permodalan. Hal ini dapat dilihat dari hubungan kinerja PPL dan kinerja Gapoktan tidak terlihat nyata. Lippitt et al. (1958) yang menyatakan bahwa agen perubahan harus memiliki kemampuan dalam melihat beberapa kasus sebagai fenomena rumit yang dapat dikenali yang dapat dimengerti, menentukan teknik dalam mengumpulkan informasi tentang setiap perubahan yang dialami sasarannya, merencanakan hubungan yang baik dengan sasarannya.

Penggunaan Poktan maupun Gapoktan dalam pengembangan pertanian melalui 
penyuluhan menyebabkan PPL harus memiliki kemampuan manjerial sehingga mampu memberikan pembinaan kepada Poktan dan Gapoktan. Hal ini sesuai dengan pernyataan Slamet (2003), para penyuluh pertanian perlu disiapkan dengan baik untuk membina Poktan dan mengembangkan kepemimpinan Poktan agar Poktan itu tumbuh menjadi Poktan yang dinamis.

\section{Kesimpulan}

Gapoktan yang memiliki jenis usaha komoditas yang beragam (heterogen) memiliki kinerja yang lebih baik daripada Gapoktan yang hanya memiliki jenis usaha yang sama (homogen)

Faktor internal yang berhubungan nyata dengan kinerja Gapoktan adalah kegiatan Poktan, kekompakan Poktan, interaksi antar Poktan, struktur organisasi dan kepemimpinan. Letak, partisipasi anggota Gapoktan dan proses pengambilan keputusan tidak berhubungan nyata dengan kinerja Gapoktan.

Faktor eksternal yang berhubungan nyata dengan kinerja Gapoktan adalah kebijakan pemerintah, hubungan dengan lembaga lain, bantuan permodalan dan intensitas penyuluhan. Kinerja PPL tidak berhubungan nyata dengan kinerja Gapoktan.

\section{Daftar Pustaka}

Dasgupta P, Ismail. 1999. Social Capital: $a$ multyfaceted perspective. Washington: the international bank for reconstruction and development/word bank.

[Deptan] Departemen Pertanian. 2006. Pedoman Umum Skim Pelayanan Pembiayaan Pertanian (SP-3). Sekretariat Jenderal Departemen Pertanian.

Hermanto R. 2007. Rancangan Kelembagaan Tani Dalam Implementasi Prima Tani di Sumatera Selatan. J Analisis Kebijakan Pertanian Vol 5(2):110-125.

Hernanto. 1996. Ilmu Usahatani. Jakarta: Penebar Swadaya.

Laksono AA. 2005. Peranan Penyuluhan Pertanian Terhadap Kinerja Kelompok
Tani (Studi Kasus di Kecamatan Sukodono Kabupaten Lumajang).

Lippitt R., Jeanne Watson, Bruce Westley. 1958. The Dynamics of Planned Change: A Comparative Study of Principles and Techniques. New YorkChicago-San Francisco-Atlanta

Popenoe D. 1989. Sociology. New Jersey: Prentice-Hall, Inc.

Rogers EM, Shoemaker FF. 1995. Соттиnication of Innovations: A Cross Cultural Approach. New Edition. New York: The Free Press

Sanders IT. 1958. The Community: an Introduction to a Sosial Sistem. The Ronald Press Company.

Setiawan AP. 2003. Kelompok, Organisasi dan Kepemimpinan. Bogor: Penerbit Tirta Kencana.

Slamet M. 2003. Membentuk Pola Perilaku Manusia Pembangunan. Yustina I dan Sudrajat A, Editor. Bogor: IPB Press.

Subarna T, Agus M, Purwanto. 2006. Pengaruh Penyuluhan Terhadap Kinerja Kelompok Usaha Agribisnis Terpadu (Kasus di Kelompok Mekar Tani Kabupaten Kuningan). J Pengkajian dan pengembangan Teknologi Pertanian. Vol 9(1):50-59.

Sujak A. 1990. Kepemimpinan Manajer (Eksistensinya dalam Perilaku Organisasi). Jakarta: Rajawali Press

Tamba, M. 2007. Kebutuhan Informasi Pertanian dan Aksesnya Bagi Petani sayuran: Pengembangan Model Penyediaan Informasi Pertanian dalam Pemberdayaan Petani, Kasus di Provinsi Jawa Barat. [disertasi]. Bogor: sekolah Pasca Sarjana IPB.

Wahyuni, S. 2003. Kinerja Kelompok Tani dalam Sistem Usaha Tani Padi dan Metode Pemberdayaannya. J Litbang Pertanian. Vol 22(1):1-8. 